\title{
Anaerobic degradation of oleic acid by suspended and granular sludge: identification of palmitic acid as a key intermediate
}

\author{
M.A. Pereira, O.C. Pires, M. Mota and M.M. Alves \\ Centro de Engenharia Biológica - IBQF, Universidade do Minho, 4710-057 Braga Portugal \\ (E-mail: Madalena.alves@deb.uminho.pt)
}

\begin{abstract}
The aim of the present work was to study the maximum potential methane production in batch assays of sludge samples taken along the operation of two EGSB reactors (RI inoculated with granular sludge and RII inoculated with suspended sludge) fed with increasing oleic acid concentrations between 2 and $8 \mathrm{gCOD} / \mathrm{l}(\mathrm{HRT}=1$ day). After removing the residual substrate, the sludge was incubated in batch vials without any added carbon source. A maximum methane production rate of $152 \pm 21 \mathrm{mlCH}_{4(\mathrm{STP})} / \mathrm{gVS}$.day was obtained for the suspended sludge taken on day 70 , when oleate at a concentration of $2 \mathrm{~g} \mathrm{COD/l}$ was fed with a co-substrate (50\% COD). The maximum plateau achieved in the methane production curve was $1145 \pm 307 \mathrm{mlCH}_{4 \text { (STP) }} / \mathrm{gVS}$, obtained for the suspended sludge taken on day 162 , when oleate was fed as the sole carbon source at $6 \mathrm{~g} \mathrm{COD/I}$. The methanization rate of the adsorbed substrate was enhanced under stirring conditions and was inhibited by adding oleic acid. Extraction and GC analysis confirmed that the main adsorbed substrate was palmitate, and not oleate. Accumulated palmitate adsorbed onto the sludge and further $\beta$-oxidation was inhibited when in the presence of oleic acid. If oleic acid was removed from the medium $\beta$-oxidation proceeded with methane production. Suspended sludge was more efficient than granular sludge.
\end{abstract}

Keywords EGSB; granular sludge; LCFA; oleic acid; palmitic acid; suspended sludge

\section{Introduction}

Lipids are one of the major components of organic matter in wastewater. Along with slaughterhouses and edible oil and fat refineries, dairy product industries are important contributors for the total lipid emission (Rinzema, 1988). Lipids are easily hydrolysed to Long Chain Fatty Acids (LCFA), which are further converted to acetate and hydrogen through $\beta$-oxidation mechanism by the proton reducing acetogenic bacteria (Weng and Jeris, 1976). LCFA are especially problematic compounds for anaerobic wastewater treatment. Tentative application of granule-based digesters to lipid-containing wastewaters revealed that, although granular sludge was more resistant to LCFA toxicity than suspended or flocculent sludge, physical stability of granules is critical for lipid containing wastewaters. This problem arises because these compounds adsorb onto the biomass and, besides the acute toxic effect, induce granular sludge flotation, which occurs for concentrations far below the toxicity limit (Hwu et al., 1998). Results from batch assays suggested that LCFA exert a bactericidal effect on methanogenic bacteria and no adaptation was observed. The recovery after a lag phase usually observed in batch assays was attributed to the growth of few survivors (Rinzema, 1998). However, results from continuous experiments with a gradual replacement of a co-substrate by oleic acid $\left(\mathrm{C}_{18: 1}\right)$, revealed that acetoclastic bacteria increased the tolerance to oleic acid toxicity (Alves et al., 2001). Moreover, a digester inoculated with an acclimated sludge exhibited higher methane yields than a digester inoculated with a non-acclimated sludge (Pereira et al., 2001).

In a continuous digester fed with oleate at concentrations as high as $12 \mathrm{gCOD} / \mathrm{L}$ 
anaerobic sludge became encapsulated by a whitish matter, which was a priori supposed to be oleic acid. When this encapsulated sludge was incubated in batch vials, after two consecutive washings for removing the residual substrate, methane was produced at a rate of $99 \mathrm{ml}$ $\mathrm{CH}_{4(\mathrm{STP})} / \mathrm{gVSS}$.day, achieving a plateau of $736 \pm 20 \mathrm{ml} \mathrm{CH}_{4(\mathrm{STP})} / \mathrm{gVSS}$, without any added carbon source. This methane production rate seemed to be delayed when oleic acid was added to the vials (Alves et al., 2001). The aim of the present work was to characterize the potential maximum methane production from the adsorbed substrate exhibited by the sludge of two EGSB reactors fed with increasing loads of oleic acid. Behaviour of granular and suspended sludge was compared. Sodium oleate was used as a LCFA model since it is, in general, the most abundant of all LCFA present in wastewater (Komatsu et al., 1991) as well as one of the more toxic (Galbraith et al., 1971).

\section{Methods}

\section{Experimental set-up and operation mode}

Two 101 EGSB reactors (RI and RII) were operated in parallel with increasing oleate concentrations between 2 and $8 \mathrm{~g} \mathrm{COD} / 1$. Hydraulic retention time was set at 1 day. RI was inoculated with granular sludge and had an internal settler. RII was inoculated with suspended sludge and was equipped with an external settler. The amount of adsorbed substrate and the corresponding potential maximum degradation rate were evaluated for a range of oleate loading rate between 2 and $8 \mathrm{~kg} \mathrm{COD} / \mathrm{m}^{3}$.day. In both digesters, a significant amount of sludge accumulated in a floating layer.

\section{Batch experiments}

For each applied oleate loading rate, samples from the bottom and top layers were collected, washed and centrifuged twice with anaerobic basal medium and incubated in batch vials of $25 \mathrm{ml}$ at $37^{\circ} \mathrm{C}, 150 \mathrm{rpm}$ under strict anaerobic conditions, without any added substrate. The methane production was followed by measuring the pressure developed in each vial, using a hand-held pressure transducer capable of measuring a pressure variation of two bar ( 0 to $\pm 202.6 \mathrm{kPa}$ ) over an output range of -200 to $+200 \mathrm{mV}$ (Colleran et al., 1992). The basal medium used in all the batch experiments, made up with demineralised water, was composed of cysteine-HCL $(0.5 \mathrm{~g} / \mathrm{l})$ and sodium bicarbonate $(3 \mathrm{~g} / \mathrm{l})$, the $\mathrm{pH}$ was adjusted to 7.0-7.2 with $\mathrm{NaOH} 8 \mathrm{~N}$ and was prepared under strict anaerobic conditions. No calcium or trace-nutrients were added. The initial maximum methane production rate and the maximum plateau achieved were determined for each vial. Values were corrected for Standard Temperature and Pressure (STP) conditions. Methanogenic activity, toxicity and biodegradability tests were also performed using this technique. All the batch experiments were performed in triplicate assays.

\section{Substrate}

In the first 70 days the substrate was made of skim milk (50\% COD) and oleic acid (50\% COD). From day 70, the carbon source was exclusively oleic acid. Macro- and micro-nutrients were added according to the composition described elsewhere (Alves et al., 2001).

\section{Seed sludge}

The granular sludge was obtained from an UASB treating a brewery effluent located in Oporto, Portugal. Suspended sludge was collected from a laboratory digester treating an oleic acid synthetic effluent. Before inoculation this sludge was incubated in batch during about 15 days, in order to degrade the adsorbed substrate. 1.61 of granular sludge $(20.2 \mathrm{~g}$ $\mathrm{VSS} / \mathrm{l})$ and 21 of suspended sludge (18.0 g VSS/l) were added to the digesters RI and RII, respectively. Both inocula were characterized in terms of specific methanogenic activity, 
oleic acid toxicity towards acetoclastic bacteria and oleic acid biodegradability. Table 1 summarizes the corresponding results.

Granular sludge exhibited activities significantly higher than suspended sludge for acetoclastic, hydrogenophilic and syntrophic propionate and ethanol degrading bacteria. Only methanogenic activity with butyrate as substrate was non-detectable in this sludge whereas a value of $52 \mathrm{ml} \mathrm{CH}_{4 \text { (STP) }} / \mathrm{gVSS}$.day was detected in the suspended sludge. The toxicity limit of oleic acid towards acetoclastic bacteria was higher for the granular than for the suspended sludge, which agrees with the work of Hwu et al. (1996). The biodegradation rate was slightly, but not significantly higher in the granular than in the suspended sludge, for the range of concentrations studied.

\section{Extraction and GC analysis of LCFA adsorbed onto the sludge}

Samples from the reactors were collected washed and centrifuged (4,000 rpm, $10 \mathrm{~min})$ twice with the anaerobic basal medium. An aliquot of each sample was dried at $105^{\circ} \mathrm{C}$, weighted and placed into separating funnels. A solution of internal standards (C7 and C15) was added to the sample, and, after acidification to $\mathrm{pH} 2$, a multiple extraction with $5 \times 1 \mathrm{ml}$ of petroleum ether was applied. The ether phase was transferred to glass vials, immediately capped, and stored at $-4^{\circ} \mathrm{C}$. LCFAs concentration was determined by a gas chromatograph (CP-9001 Chrompack) equipped with a flame ionization detector (FID) and a split/splitless injector. LCFAs were separated on a FFAP-CB $25 \mathrm{~m} \times 0.32 \mathrm{~mm} \times 0.3 \mu \mathrm{m}$ column (Chrompack), using nitrogen $\left(\mathrm{N}_{2}\right)$ as carrier gas at $35 \mathrm{KPa}, 30: 1$ split rate. Oven temperature was $40^{\circ} \mathrm{C}$ for $2 \mathrm{~min}$, with a $5^{\circ} \mathrm{C} / \mathrm{min}$ ramp to $250^{\circ} \mathrm{C}$, and a final hold at $250^{\circ} \mathrm{C}$ for $15 \mathrm{~min}$.

\section{Results and discussion}

Table 2 summarises the operating conditions and performance of RI and RII. During the first 70 days skim milk was introduced as a co-substrate, representing $50 \%$ of the total COD fed. For the first two operating conditions, RI exhibited higher removal efficiencies and higher methane production than RII, but in the last two operation periods, higher methane productions and lower VSS levels were obtained in RI. From day 70 onwards, oleate was the sole carbon source fed to both digesters, and the methane production decreased to $20-30 \%$ of the initial value. Along the trial period the methane yield decreased from 289 and $242 \mathrm{lCH}_{4} / \mathrm{kg} \mathrm{COD}$ removed 27 and $391 \mathrm{CH}_{4} / \mathrm{kg} \mathrm{COD}_{\text {removed }}$ in RI and RII, respectively. Figure 1 represents the results from the batch experiments for the sludge taken from RI and

Table 1 Methanogenic activity, oleic acid toxicity and biodegradability for the granular and suspended seed sludge ( $\pm 95 \%$ confidence interval)

\begin{tabular}{ccc}
\hline & Granular & Suspended \\
\hline Methanogenic activity in presence of: & $\left(\mathrm{mlCH}_{4(\mathrm{STP})} / \mathrm{gVSS} \cdot\right.$ day $)$ & \\
Acetate & $327 \pm 11$ & $107 \pm 6$ \\
Propionate & $160 \pm 10$ & $48 \pm 14$ \\
Butyrate & (n.d.) & $52 \pm 3$ \\
Ethanol & $514 \pm 94$ & $106 \pm 2$ \\
$\mathrm{H}_{2} / \mathrm{CO}_{2}$ & $597 \pm 16$ & $487 \pm 31$ \\
Oleic acid toxicity limit $\left(\mathrm{IC}_{50}\right)(\mathrm{mg} / \mathrm{l})$ & $345 \pm 26$ & $133 \pm 16$ \\
Biodegradability for oleate $\mathrm{concentrations:}$ & $\left(\mathrm{mlCH}_{4(\mathrm{STP})} / \mathrm{gVSS} \cdot\right.$ day) & \\
$100 \mathrm{mg} / \mathrm{l}$ & (n.d.) & $6 \pm 1$ \\
$300 \mathrm{mg} / \mathrm{l}$ & $14 \pm 1$ & $7 \pm 2$ \\
$500 \mathrm{mg} / \mathrm{l}$ & $10 \pm 1$ & $9 \pm 1$ \\
$700 \mathrm{mg} / \mathrm{l}$ & $8 \pm 1$ & $8 \pm 2$ \\
$900 \mathrm{mg} / \mathrm{l}$ & $10 \pm 2$ & $7 \pm 2$ \\
\hline
\end{tabular}

STP - Standard temperature and pressure conditions; n.d. - non-detectable 
Table 2 Operating conditions and performance of RI and RII ( $\pm 95 \%$ confidence intervals)

\begin{tabular}{|c|c|c|c|c|c|c|c|c|c|c|}
\hline \multirow[t]{2}{*}{ Period } & \multirow[t]{2}{*}{$\begin{array}{l}\text { (days) } \\
\text { (dime }\end{array}$} & \multirow[t]{2}{*}{$\begin{array}{c}\text { HRT } \\
( \pm 0.01) \\
\text { (days) }\end{array}$} & \multirow[t]{2}{*}{$\begin{array}{l}\text { Influent } \\
\text { COD } \\
(\mathrm{g} / \mathrm{l})\end{array}$} & \multirow[t]{2}{*}{$\begin{array}{l}\text { Influent } \\
\text { oleate } \\
\operatorname{COD}(g / l)\end{array}$} & \multicolumn{2}{|c|}{$\begin{array}{l}\text { COD removal } \\
\text { efficiency } \\
(\%)\end{array}$} & \multicolumn{2}{|c|}{$\begin{array}{l}\text { Effluent VSS } \\
\quad(g / l)\end{array}$} & \multicolumn{2}{|c|}{$\begin{array}{l}\text { Methane production } \\
\left(\mathrm{ICH}_{4} / \mathrm{l} . \text { day }\right)\end{array}$} \\
\hline & & & & & $\mathbf{R I}$ & RII & RI & RII & RI & RII \\
\hline I & $0-70$ & 1.01 & $\begin{array}{c}3.8 \\
( \pm 0.3)\end{array}$ & $\begin{array}{c}1.9 \\
( \pm 0.2)\end{array}$ & $\begin{array}{c}96.5 \\
( \pm 0.6)\end{array}$ & $\begin{array}{c}85.8 \\
( \pm 3.2)\end{array}$ & $\begin{array}{c}0.38 \\
( \pm 0.07)\end{array}$ & $\begin{array}{c}0.65 \\
( \pm 0.04)\end{array}$ & $\begin{array}{c}1.06 \\
( \pm 0.1)\end{array}$ & $\begin{array}{c}0.79 \\
( \pm 0.1)\end{array}$ \\
\hline II & $70-119$ & 1.01 & $\begin{array}{c}3.8 \\
( \pm 0.3)\end{array}$ & $\begin{array}{c}3.8 \\
( \pm 0.3)\end{array}$ & $\begin{array}{c}83.4 \\
( \pm 4.8)\end{array}$ & $\begin{array}{c}74.4 \\
( \pm 5.5)\end{array}$ & $\begin{array}{c}0.85 \\
( \pm 0.22)\end{array}$ & $\begin{array}{c}0.72 \\
( \pm 0.15)\end{array}$ & $\begin{array}{c}0.23 \\
( \pm 0.05)\end{array}$ & $\begin{array}{c}0.26 \\
( \pm 0.05)\end{array}$ \\
\hline III & 119-162 & 1.01 & $\begin{array}{c}6.2 \\
( \pm 0.7)\end{array}$ & $\begin{array}{c}6.2 \\
( \pm 0.7)\end{array}$ & $\begin{array}{c}74.2 \\
( \pm 3.8)\end{array}$ & $\begin{array}{c}74.6 \\
( \pm 2.9)\end{array}$ & $\begin{array}{c}1.96 \\
( \pm 0.43)\end{array}$ & $\begin{array}{c}1.57 \\
( \pm 0.17)\end{array}$ & $\begin{array}{c}0.16 \\
( \pm 0.02)\end{array}$ & $\begin{array}{c}0.20 \\
( \pm 0.08)\end{array}$ \\
\hline IV & $162-219$ & 1.01 & $\begin{array}{c}8.2 \\
( \pm 0.5)\end{array}$ & $\begin{array}{c}8.2 \\
( \pm 0.5)\end{array}$ & $\begin{array}{c}68.8 \\
( \pm 3.4)\end{array}$ & $\begin{array}{c}69.4 \\
( \pm 5.5)\end{array}$ & $\begin{array}{c}2.71 \\
( \pm 0.57)\end{array}$ & $\begin{array}{c}2.50 \\
( \pm 0.58)\end{array}$ & $\begin{array}{c}0.15 \\
( \pm 0.02)\end{array}$ & $\begin{array}{c}0.22 \\
( \pm 0.06)\end{array}$ \\
\hline
\end{tabular}
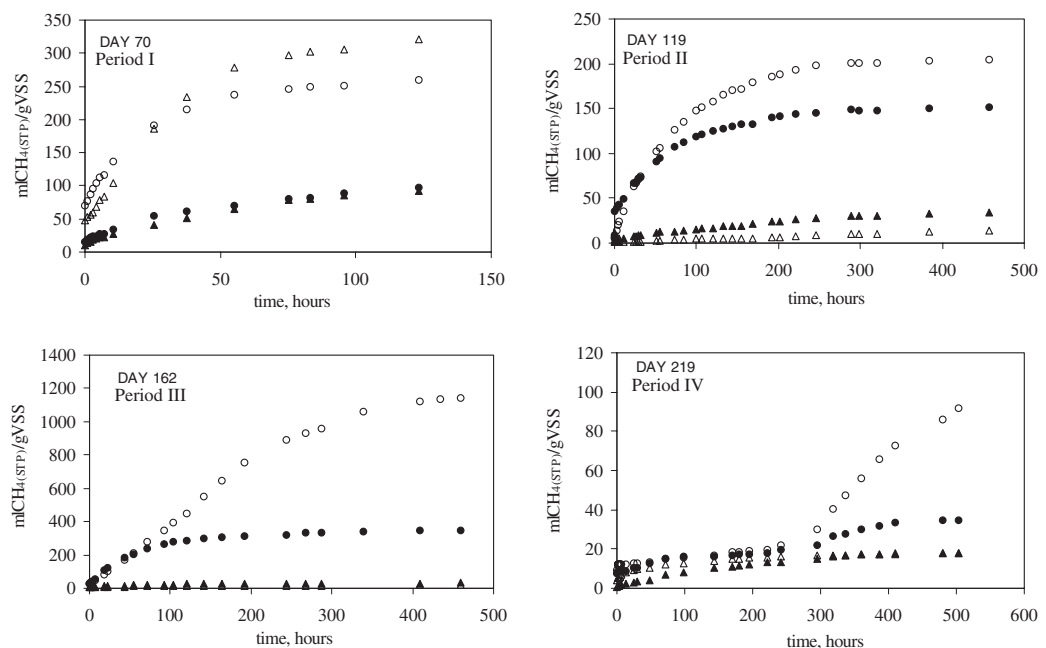

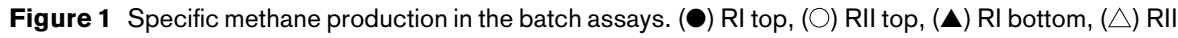
bottom

RII in the bottom and top layers at the end of operating periods I, II, III, and IV. Table 3 summarises the results obtained.

On day 162 , when oleate was fed at $6 \mathrm{~kg} \mathrm{COD} / \mathrm{m}^{3}$.day, the highest plateau in the methane production curve was obtained for the RII-top sludge $\left(1145 \pm 307 \mathrm{ml} \mathrm{CH}_{4(\mathrm{STP})} / \mathrm{gVSS}\right)$ which was more than threefold that obtained in the RI-top sludge. For the bottom sludges, no significant differences were obtained (Table 3 ).

For the oleate organic load of $8 \mathrm{~kg} \mathrm{COD} / \mathrm{m}^{3}$.day (period IV), a clear inhibition of the adsorbed substrate degradation was observed. A lag-phase of 300 hours preceded the initial methane production and a clear decrease in the methane production rates and plateaux were observed. When comparing the methane production rates in continuous operation and in batch mode for the oleate loading rate of $6 \mathrm{~kg} \mathrm{COD} / \mathrm{m}^{3} . \mathrm{d}$, in RII, it is concluded that more methane would be produced per day if the feed was suppressed, provided that optimal conditions were assured. In fact, considering the amount of VSS present in the RII top layer $(30 \mathrm{~g}), 2.61 \mathrm{CH}_{4}$ would be produced per day, whereas in continuous mode only $21 \mathrm{CH}_{4}$ were produced in the whole reactor (Table 2). This suggests adsorbed matter can be degraded efficiently, if no oleate is present. This was confirmed in batch assays (Figure 2a). When oleate was added to a sample of washed-encapsulated sludge, the methane production rate was significantly lower than that exhibited by the sludge without any added substrate. A

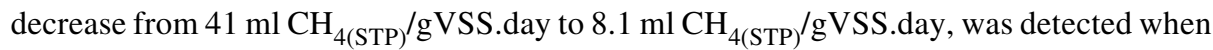


Table 3 Maximum plateaux ( $\mathrm{ml} \mathrm{CH}_{4(\mathrm{STP})} / \mathrm{gVSS}$ ) and methane production rate $\left(\mathrm{ml} \mathrm{CH}_{4(\mathrm{STP})} / \mathrm{gVSS}\right.$.day) obtained in the batch experiments $( \pm 95 \%$ confidence intervals)

\begin{tabular}{llcccc}
\hline & & RI top & RII top & RI bottom & RII bottom \\
\hline DAY 70 & Maximum "plateau" & $97 \pm 13$ & $260 \pm 28$ & $92 \pm 6$ & $321 \pm 42$ \\
Period I & Methane production rate & $40 \pm 4$ & $152 \pm 21$ & $35 \pm 6$ & $133 \pm 17$ \\
DAY 119 & Maximum "plateau" & $152 \pm 6$ & $204 \pm 41$ & $34 \pm 12$ & $14 \pm 2$ \\
Period II & Methane production rate & $30 \pm 3$ & $50 \pm 7$ & $4 \pm 1$ & $1 \pm 1$ \\
DAY 162 & Maximum "plateau" & $349 \pm 38$ & $1145 \pm 307$ & $34 \pm 2$ & $19 \pm 3$ \\
Period III & Methane production rate & $70 \pm 2$ & $85 \pm 3$ & $5 \pm 1$ & $3 \pm 1$ \\
DAY 219 & Maximum "plateau" & $35 \pm 4$ & $111 \pm 24$ & $18 \pm 1$ & $18 \pm 3$ \\
Period IV & Methane production rate & $4 \pm 1$ & $7 \pm 1$ & $3 \pm 1$ & $2 \pm 1$ \\
\hline
\end{tabular}

$100 \mathrm{mg} / \mathrm{l}$ oleic acid were added. This suggests that adsorbed matter is no longer oleic acid, but probably an intermediate of its degradation, such as stearate or palmitate (Weng and Jeris, 1976).

Experiments made under static and stirring conditions led to the conclusion that methane production rate is significantly enhanced by stirring as can be observed in Figure 2b. A lag phase of about 300 hours was observed preceding the initial methane production under static conditions. As the substrate is already in intimate contact with the biomass, substrate diffusion limitations are not expected to limit the degradation rate. However, product diffusion limitation, e.g. biogas release was observed to be difficult under static conditions, which may justify the different methane production patterns.

Figure 3 represents a phase contrast microphotograph from the encapsulated sludge where a very clear whitish zone is detected. The extraction and GC analysis of this adsorbed matter confirmed the suspicion that it was not composed mainly of oleic acid. Only traces of this LCFA were detected and palmitate was the main compound detected (Figure 4).

This is evidence that accumulated palmitic acid adsorbed onto the sludge and further $\beta$ oxidation was inhibited in the presence of oleic acid. In batch assays, when oleic acid was removed from the medium, $\beta$-oxidation proceeded with methane production. The maximum accumulated palmitate and the rate of methane production were highly dependent on biomass structure, suspended sludge being more efficient than granular sludge. From these results it can be concluded that for treating effluents with high lipid content, it should be advantageous to sequence cycles of adsorption and degradation in order to enhance methane production.

\section{Conclusions}

Operation of two EGSB reactors (RI inoculated with granular sludge and RII inoculated with suspended sludge) fed with oleic acid as the sole carbon source revealed that methane production decreased to $20-30 \%$ of the value exhibited when a co-substrate was fed as $50 \%$
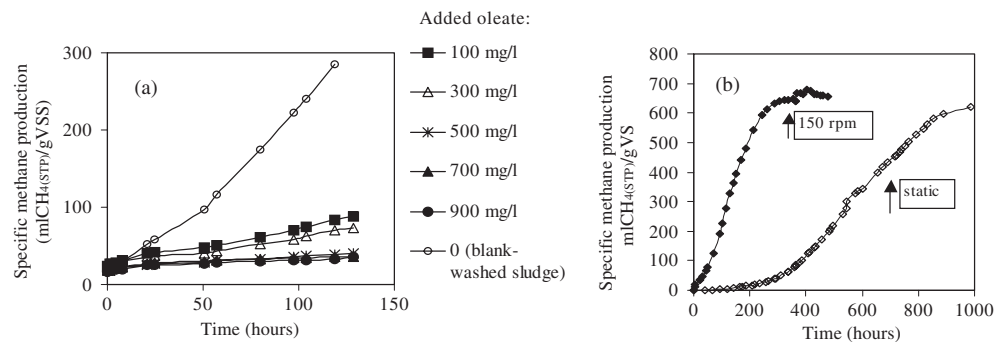

Figure 2 Effect of adding oleate; (a) effect of stirring and (b) in specific methane production in batch assays. 


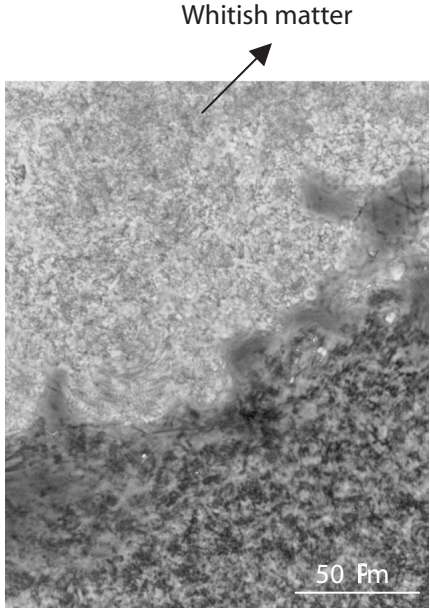

Figure 3 Microscopic examination of encapsulated sludge

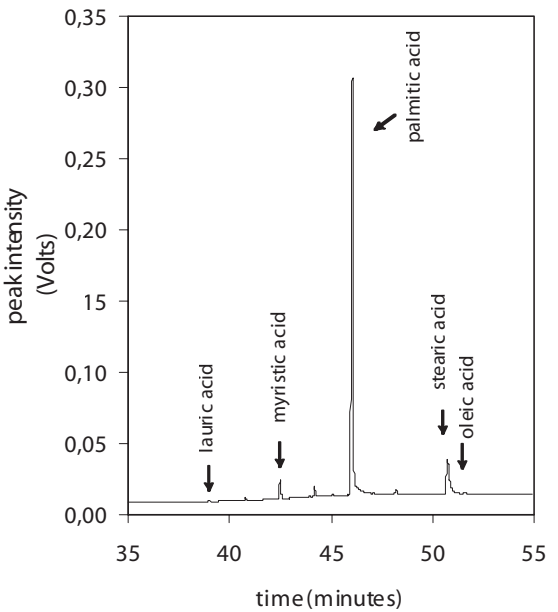

Figure 4 Example of a chromatogram obtained by $\mathrm{GC}$ analysis after extraction of the adsorbed matter

COD. Methane yields as low as $25 \mathrm{lCH}_{4} / \mathrm{kg}$ COD removed, were obtained. Maximum rate of methane production due to degradation of adsorbed substrate in batch vials was $152 \pm 21 \mathrm{mlCH}_{4(\mathrm{STP})} / \mathrm{gVS}$.day obtained for the suspended sludge taken on day 70, when oleate at a concentration of $2 \mathrm{~g} \mathrm{COD} / 1$ was fed with a co-substrate (50\% COD). The maximum plateau achieved in the methane production curve was $1145 \pm 307 \mathrm{mlCH}_{4(\mathrm{STP})} / \mathrm{gVS}$, obtained for the RII-suspended sludge taken on day 162, when oleate was fed as the sole carbon source at $6 \mathrm{~g} \mathrm{COD} / 1$.

The degradation of the adsorbed substrate was inhibited by adding oleic acid and was enhanced by stirring conditions. Extractions and gas cromatography (GC) analysis of the adsorbed matter revealed that it was mainly composed of palmitic acid. Accumulated palmitic acid adsorbed onto the sludge and further $\beta$-oxidation was inhibited in the presence of oleic acid. When oleic acid was removed from the medium (batch experiments), $\beta$-oxidation proceeded with methane production. When treating effluents with high lipid content, it should be advantageous to run sequencing cycles of adsorption and degradation in order to enhance methane production. Provided that it can be retained in the reactor, suspended sludge is advantageous over granular sludge due to its higher capacity of LCFA adsorption and degradation.

\section{References}

Alves, M.M., Mota Vieira, J.A., Álvares Pereira, R.M., Pereira, M.A., Novais, J.M. and Mota M. (2001). Effects of lipids and oleic acid on biomass development in anaerobic fixed reactors. Part II: Oleic acid toxicity and biodegradability. Wat. Res. 35(1), 264-270.

Colleran, E., Concannon, F., Goldem, T., Geoghegan, F., Crumlish, B., Killilea, E., Henry, M. and Coates, J. (1992) Use of methanogenic activity tests to characterize anaerobic sludges, screen for anaerobic biodegradability and determine toxicity thresholds against individual anaerobic trophic groups and species. Wat. Sci. Technol., 25(7), $31-40$.

Galbraith, H., Miller, T.B., Paton, A.M. and Thomson, J.K. (1971). Antibacterial activity of long chain fatty acids and the reversal with calcium, magnesium, ergocalciferol and cholesterol. J. Appl. Bact. 34, 803-813.

Hwu, C.-S., Donlon, B. and Lettinga, G. (1996). Comparative toxicity of long-chain fatty acid to anaerobic sludges from various origins. Wat. Sci. Technol. 34(5/6), 351-358.

Hwu, C.-S., Tseng, S.-K., Yuan, C.-Y., Kulik, Z. and Lettinga, G. (1998). Biosorption of long-chain fatty acids in UASB treatment process. Wat. Res., 32(5), 1571-1579.

Komatsu, T., Hanaki, K. and Matsuo, T. (1991). Prevention of lipid inhibition in anaerobic processes by introducing a two-phase system. Wat. Sci. Technol. 23(7/9), 1189-1200.

Pereira, M.A., Mota, M. and Alves, M.M. (2001). "Degradation of oleic acid in anaerobic filters: effect of inoculum acclimatization and biomass recirculation. Wat. Environ. Res. (in press).

Pires, O.C, Pereira, M.A. Alves, M.M. and Mota, M. (2001). "Extraction and analysis of long chain fatty acids adsorbed onto active and inactivated anaerobic sludge", 9th World Congress on Anaerobic Digestion, Proceedings Part 2, Antwerpen, Belgium, September 2-5, 469-471.

Rinzema, A. (1988). Anaerobic treatment of wastewater with high concentration of lipids or sulfate. Ph.D. Thesis, Wageningen Agricultural University, The Netherlands.

Weng, C.-N. and Jeris, J.S. (1976). Biochemical mechanisms in the methane fermentation of glutamic and oleic acids. Wat. Res. 10, 9-18. 